\title{
A NEW APPROACH IN TREATMENT ACUTE IVERMECTIN TOXICITY IN MALE BALB-C MICE
}

\author{
F. M. K . Al-Rekabi ${ }^{1}$ \\ A. Alsadawi ${ }^{2}$ \\ $\begin{array}{ccc}\text { Assist Prof. } & \text { Lecturer } & \text { Lecturer } \\ { }^{1} \text { Dept of Phys, Bioch and Pharma, Coll of Vet Med, University of Baghdad, Iraq }\end{array}$ \\ $\begin{array}{ccc}\text { Assist Prof. } & \text { Lecturer } & \text { Lecturer } \\ { }^{1} \text { Dept of Phys, Bioch and Pharma, Coll of Vet Med, University of Baghdad, Iraq }\end{array}$ \\ Ali. I. Al-ameedi ${ }^{3}$ \\ ${ }^{2}$ Dept of Vet Public Health, Coll of Vet Med, University of Baghdad, Ira \\ ${ }^{3}$ Dept of phys and Pharmacology,Coll of Vet Med ,Al-Qasim Green University, Babylon-Iraq \\ Email:fab20062003@yahoo.com, falah@covm.uobaghdad.edu.iq
}

\section{ABSTRACT}

This study was conducted to investigate the potential therapeutic of flumazenil and neostigmine in single and combination in Balb-C mice subjected to ivermectin acute oral toxicity. Ivermectin-poisoning dose was considered the half dose of $\mathrm{LD}_{50}$ that computed in current study as $20.9 \mathrm{mg} / \mathrm{kg} \mathrm{BW}$. A total of $24 \mathrm{male}$ Blub-C mice were divided randomly into four equal treatment groups and administered ivermectin-poisoning dose (10 $\mathrm{mg} / \mathrm{kg} \mathrm{BW}$ ) and treated as follows: control group (C), treated orally with distilled water; neostigmine-treated group (NT), treated i.p. with $60 \mu \mathrm{g} / \mathrm{kg} \mathrm{BW}$ of neostigmine; flumazenil-treated group (FT), treated i.p. with 7 $\mu \mathrm{g} / \mathrm{kg} \mathrm{BW}$ of flumazenil; and combination-treated group (CT), treated i.p. with $30 \mu \mathrm{g} / \mathrm{kg} \mathrm{BW}$ of neostigmine plus $3.5 \mu \mathrm{g} / \mathrm{kg} \mathrm{BW}$ of flumazenil. Oral administration of ivermectin at poisoning dose caused grooming, lethargy, depression, recumbency, with no mortalities recorded. The toxic signs of animals in FT and NT groups were disappeared within 1.23 and $1.98 \mathrm{~h}$, respectively, comparing to animals in CT and C groups, in which the recovery time was prolonged to 40.62 and $4.52 \mathrm{~h}$, respectively. Overall, both flumazenil and neostigmine medicines have the potential to overcome ivermectin acute poisoning in Bulb-C mice, with flumazenil being more efficient. However, the combination of both medicines can cause an adverse prognosis.

Keywords: Ivermectin, flumazenil, neostigmine, Balb-C

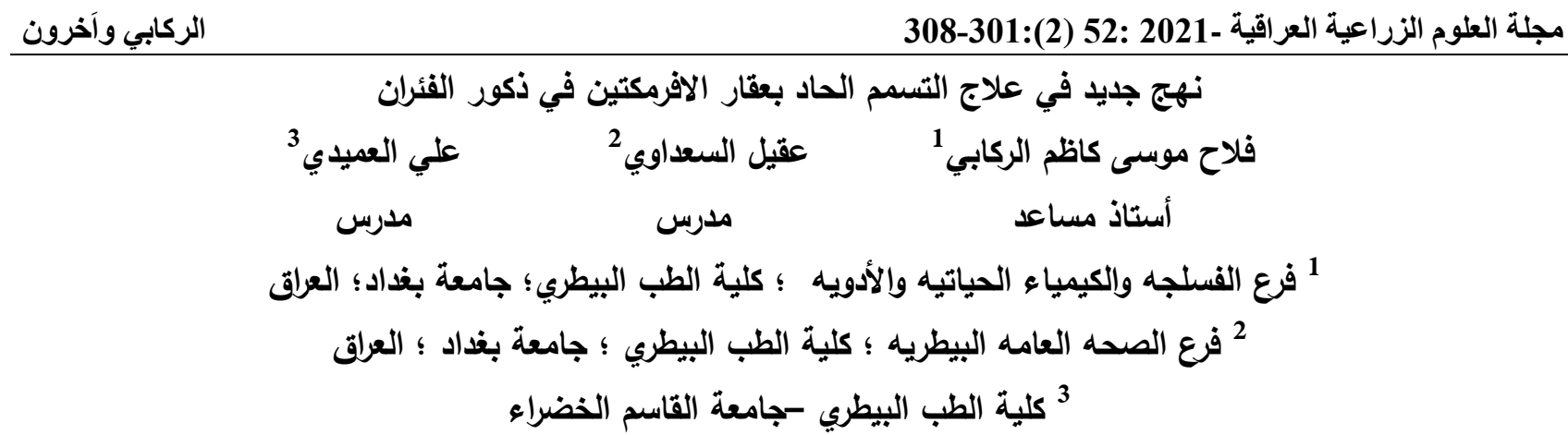

المستخلص

أجريت هذه الدراسد لتقصي القابلية العلاجيه لعقاري الفلومازنيل والنيوستكمين كل بصورة منفره ومزيجهما في الفئران المسممه بجرعه عاليه مفرده من الافرمتين ـ تم تحديد الجرعة السمية الحاده إعتمادا على حساب الجرعة النصف قاتله لعقار الافرمكتين بطريقة الصعود والنزول ويعدها تم إختيار نصفها تقريبا واستخدمت في التجرية العلاجيه. كانت الجرعة الفمويه النصف قاتله 9 و 20 ملفم/كغم من وزن الجسم .أستخدم أربعة وعشرون فأرا لتقييم القابلية العلاجيه لعقاري الفلومازنيل والنيوستكمين ومزيجهما ؛ قسمت الحيوانات عشوائيا الى أربعة مجاميع متساويه وإستحدث التسمم الحاد بالافرمتين بجرعة 10 ملفم /كفم من وزن الجسم فمويا وتم معاملة المجاميع كما يلي : مجموعة السيطره(C) عولجت فمويا بالماء المقطر ؛ مجموعة

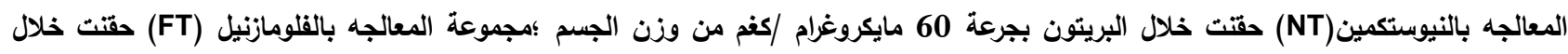

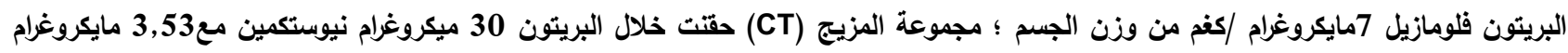
فلومازنيل /كفم من وزن الجسم.أظهرت الحيوانات التي جرعت فمويا بالجرعة السامة من الافرمكتين أعراض سرئ سريريه تراوحت بين الإستدراج ؛ الكسل ؛كابه ورقاد بدون هلاكات ـ إختفت الأعراض السميه للافرمكتين في مجموعتي المعالجة بالفلومازنيل والنيوستكمين بصوره ملحوضه حيث إختفت

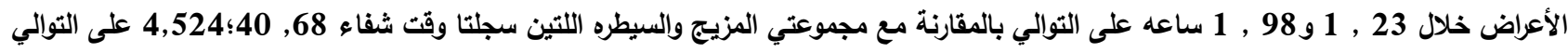
• يمكن الإستنتاج بأن كلا عقاري الفلومازنيل والنيوستكمين لهما القابلية على كبح التسمم الحاد بالافرمكتين في الفئران حيث كان عقار الفلومازنيل الأكثر فعاليه بينما سبب مزيج الفلومازنيل والنيوستكمين مالا سيئا.

الكلمات المفتاحية: الافرمكتين؛ فلومازنيل؛ نيوستكمين؛ الفئران 


\section{INTRODUCTION}

Ivermectin is a macrocyclic lactone, broadspectrum antiparasitic $(18,14)$. It has been evolved over the last three decades from being a veterinary "blockbuster" drug to a panacea for nematodal infestation and ectoparasitic diseases in humans (5), and widely used as a drug for the treatment of parasitic infection in laboratory rodents (16). Ivermectin as insecticide mediates its activity through potentiation gamma aminobutyric acid (GABA) neural and neuromuscular transmission, while mammals are relatively resistant to ivermectin poisoning as they have only central GABA-ergic synapses protected by the blood-brain barrier. However, at high doses, ivermectin may penetrate the bloodbrain barrier. It was reported that the peak of the ivermectin level in the brain reaches between 2-4 hs after administration. In mammalian species, CNS depression and ataxia are the most observed symptoms seen as a result of inhibitory GABA-ergic synapses(8). Ivermectin augments the release of GABA at presynaptic neurons. It is absorbed up to $95 \%$ after oral administration in simple stomached animals (17). Acute toxicity investigated in dogs received $40 \mathrm{mg} / \mathrm{kg}$ BW orally and death due to respiratory depression (7). Likewise, dogs administered $2 \mathrm{mg} / \mathrm{kg}$ BW showed tremors, ataxia, anorexia, and developed dehydrated (17). Kittens received $7.5 \mathrm{mg} / \mathrm{kg}$ $\mathrm{BW}$, which is corresponding to 125 fold of recommended therapeutic dose, developed ataxia, salivation, and comatose within 24 hs. These animals were treated by $25 \mu \mathrm{g}$ neostigmine methyl sulfate plus $5 \%$ dextrose saline $(20 \mathrm{ml})$ I.V. showed transient improvement but died after $12 \mathrm{~h}$ (8). In a certain case of calf administered a bolus contained $100 \mathrm{mg}$ ivermectin, developed various clinical signs included mydriasis, absence of pupillary and menace reflex, sticky salivation, normal body temperature, tachycardia, tachypnoea, dull, depressed, sudden fall with tremors, abnormal posture and gait. The animals were treated by activated charcoal (2g/kg BW PO TID), Diazepam (0.5 $\mathrm{mg} / \mathrm{kg}$ bid) up to the disappearance of clinical signs, and aggressive fluid therapy was given for three days. Supportive treatment included intramuscular injection of theophylline
$(6.6 \mathrm{mg} / \mathrm{kg} \mathrm{BW})$, vitamin B-complex with liver extract $(3 \mathrm{~mL})$, chlorpheniramine maleate (Avil) at $0.5 \mathrm{mg} / \mathrm{kg}$ BW daily for five days. A slight improvement was seen in calf after three days and complete recovery after five days of treatment (19). The main concern is the neurotoxicity, which in most mammalian species may manifest as central nervous system depression, and consequent ataxia as might be expected from potentiating of inhibitory GABA-ergic synapses $(2,15)$.

Flumazenil, an imidazobenzodiazepine, has a very rapid onset of action after parenteral administration. The affinity of flumazenil is between the $\alpha$ and $\gamma 2$ subunits of the GABA receptor, close to the benzodiazepine binding site (13). The predominant receptor composed of $\alpha 1$ mediates sedation and muscle relaxation, those with $\alpha 2$ or $\alpha 3$ anxiolysis and anticonvulsant effects and the extrasynaptic receptor with $\alpha 5$ amnesia (1). Neostigmine is an anticholinesterase, and this allows ACh to persist for a longer period enhancing transmission across neuromuscular junctions and causes muscle contraction (10). Due to accidental and improper use of ivermectin in both human and animals (8), a wide range of different cases of ivermectin toxicity have been occurred. As a result, different strategies to treat ivermectin toxicity have been developed. However, some of them are not fully effective, and developing a new approach to overcome ivermectin acute toxicity is still in need. Therefore, the objective of this study was to design another strategy to treat ivermectin acute toxicity in mice and to establish its effectiveness.

\section{MATERIALS AND METHODS \\ Animals and management}

The other 24 mice were used in the acute toxicity study of ivermectin. The study carried out after approval of the Scientific Committee in the Department of Physiology, Biochemistry, and Pharmacology, College of Veterinary Medicine, University of Baghdad in accordance with ethical standards of animal welfare. A total of thirty male Balb-C mice (23 months) weighting 20-30 g were raised and bred for one month before beginning the study for acclimatization in the animal house of 
College of Veterinary Medicine, University of Baghdad. Tap water and standard pellet diet were provided ad libitum. Six of them were used for determining the $\mathrm{LD}_{50}$ of ivermectin by the Up and Down method (6). Medicines and administration methods: All medicines used in this study were purchased from suppliers as indicated for each one: Kepromic ${ }^{\circledR}$ oral ivermectin (KEPRO B.V., Holand), neostigmine (Hameln phamacenticals $\mathrm{GmbH}$, Germany), and flumazenil (Sandoz, Canada). Dosage rates of all medicines administered to mice by different routes were achieved by fitting the concentrations for getting a dose volume of $0.1 \mathrm{~mL} / 10 \mathrm{~g} \mathrm{BW}$ of mice. All medicines were dissolved in distilled water.

\section{Experimental design}

To induce ivermectin toxicity in Bulb-C mice, the half dose of $\mathrm{LD}_{50}$ was chosen as the toxic dose. $\mathrm{LD}_{50}$ was estimated using 6 animals by the Up and Down method as described previously (6). The other 24 mice were subjected for conduction treatment of acute toxicity of ivermectin. They were divided equally into four groups and administered single ivermectin-poisoning dose at $10 \mathrm{mg} / \mathrm{kg}$ BW (half dose of $\mathrm{LD}_{50}$ as estimated in the current study) and treated as follows: Control group (C), treated orally with distilled water through gastric gavage; neostigmine-treated group (NT), treated intraperitoneally with neostigmine at $60 \mu \mathrm{g} / \mathrm{kg} \mathrm{BW}$; flumazeniltreated group (FT), treated intraperitoneally with flumazenil at $7 \mu \mathrm{g} / \mathrm{kg} \quad \mathrm{BW}$; and combination-treated group (CT), treated intraperitoneally with neostigmine at $30 \mu \mathrm{g} / \mathrm{kg}$ BW plus flumazenil at $3.5 \mu \mathrm{g} / \mathrm{kg} \mathrm{BW}$. Treatment with medicines started as soon as the signs of ivermectin toxicity had risen. The number of cured and dead animals in each group and time of recovery from poisoning were recorded and considered as criteria of treatment effectiveness.

Statistical analysis Data of time recovery were analyzed as one way-ANOVA using the GLM procedure of SPSS software version 22.00 (IBM SPSS Inc., Chicago, IL, USA). Means were separated using LSD at $P<0.05$. Results presented as Mean \pm SEM. Individual animals were considered the experimental unit (11).

\section{RESULTS AND DISCUSSION}

The acute toxicity study found that the oral $\mathrm{LD}_{50}$ of ivermectin as estimated by the Up and Down method is $20.9 \mathrm{mg} / \mathrm{kg} \mathrm{BW}$ in male Balb-C mice for $24 \mathrm{~h}$ (Table 1). The ivermectin is considered an extremely toxic agent with grade 5 according to the classification of toxicity rating which depends on $\mathrm{LD}_{50}$ value (12). This outcome means that at approximate teaspoonful of ivermectin orally may cause lethality in an adult human.

The signs exhibited by morbid mice are listed in Table 2. These signs have nearly resembled previous acute studies conducted in mice, rats, rabbits, dogs, and monkeys. The typical signs of acute ivermectin toxicity were all attributed to effects on the central nervous system. These signs were most severe in $\mathrm{CF}-1$ mice, which exhibited ataxia, bradypnoea, and tremors. The death occurred from approximately one to six $\mathrm{h}$ after treatment as reported by (24), however, the death in the present study occurred between 6-9 h. Also, various clinical signs of ivermectin poisoning have been reported in human (9), in which some of these signs were compatible with what we found such as increased salivation, diarrhoea, difficult breathing, muscle fasciculation, drooping of lips, bilateral mydriasis, depression, ataxia, recumbency, reduced pupillary reflex, absent menace reflex, rarely encephalopathy, and death. Serious neurological adverse events have been reported from large scale community-based ivermectin treatment campaigns against onchocerciasis volvulus in Africa (4). In our not published work, we also observed bradypnoea and mydriasis in local Iraqi rabbits exposed subcutaneously to a single dose $(33.7 \mathrm{mg} / \mathrm{kg} \mathrm{BW})$ of ivermectin that is resembled the half $\mathrm{LD}_{50}$ we estimated in this animal species. This draws attention that ivermectin poisoning is variable in different animal species and route of administration. 
Table 1. Oral $\mathrm{LD}_{50}$ of ivermectin in male Balb-C mice as calculated by Up and Down method $^{1}$

\begin{tabular}{|cccccc|}
\hline $\begin{array}{c}\text { Initi } \\
\text { al } \\
\text { dose }\end{array}$ & $\begin{array}{c}\text { Last } \\
\text { dose }\end{array}$ & $\begin{array}{c}\text { Difference } \\
\text { between } \\
\text { doses }\end{array}$ & $\begin{array}{c}\text { Number of } \\
\text { animals }\end{array}$ & $\begin{array}{c}\text { Results after } \\
48 \mathbf{h}^{*}\end{array}$ & LD $_{50}{ }^{* *}$ \\
\hline 100 & 40 & 20 & 6 & XXOXXO & 20.9 \\
\hline
\end{tabular}

O=Survival animal, $X=$ Dead animal

${ }^{* * *}{ }^{L} D_{50}=x f+k d$, where: $\mathbf{x f}=$ final dose; $k$ (constant) $=\mathbf{0 . 8 6 0}, \mathrm{d}=$ differences between doses (Dixon, 1980)

${ }^{1}$ All doses are in $\mathrm{mg} / \mathrm{kg} \mathrm{BW}$

The result of current study showed that oral administration of ivermectin at poisoning dose, which was considered as the half dose of $\mathrm{LD}_{50}$ calculated, caused grooming, lethargy, depression, recumbency, and with no mortalities recorded. These acute toxic signs were relieved within $1.23 \pm 0.01 \mathrm{~h}$ in animals of the FT group, which treated with flumazenil at $7 \mu \mathrm{g} / \mathrm{kg} \mathrm{BW}$. This reduction in time recovery was significantly $(P<0.05)$ lesser than the ones recorded in animals of $\mathrm{C}(4.52 \pm 0.10 \mathrm{~h}$, treated with distilled water), NT (1.98 $\pm 0.15 \mathrm{~h}$, treated with $60 \mu \mathrm{g} / \mathrm{kg}$ BW neostigmine), and CT $(40.25 \pm 2.78 \mathrm{~h}$, treated with $30 \mu \mathrm{g} / \mathrm{kg} \mathrm{BW}$ of neostigmine plus $3.5 \mu \mathrm{g} / \mathrm{kg} \mathrm{BW}$ of flumazenil) groups (Figure 1). These findings nearly resemble the result of (25) who found that flumazenil at $0.2 \mathrm{mg} / \mathrm{kg} \mathrm{BW}$ significantly reduced the sleeping time in rats treated with a combination of ivermectin $(10 \mathrm{mg} / \mathrm{kg} \mathrm{BW})$ and thiopentone $(25 \mathrm{mg} / \mathrm{kg} \mathrm{BW})$. However, we found that flumazenil at $7 \mu \mathrm{g} / \mathrm{kg} \mathrm{BW}$, which is approximately equal to 0.035 of the dose used by Trailović and Nedeljković (25), was able to relieve the acute toxic signs of ivermectin. The difference between the dose amounts may be due to species variation, route of administration, criteria considered as an indication of recovery, and the agents used to induce acute toxicity. Ivermectin is thought to promote the release of GABA and/or acts as a GABA receptor agonist, thus raising the GABA-induced chloride conductance which results in hyperpolarization of the neuron (22,23, and 26). We believe that as flumazenil is GABA antagonists, it can inhibit the action of $\mathrm{GABA}$ and consequently counteract the toxic effect of ivermectin. In general, these drugs (GABA antagonists) produce a convulsion effect, which is confirmed with the appearance of convulsion for short period (disappeared within minutes), in the mice after administration flumazenil. The animals in NT group (treated with $60 \mu \mathrm{g} / \mathrm{kg} \mathrm{BW}$ neostigmine intraperitoneally) showed a non-significant decrease in time needed to recover the acute toxic signs of ivermectin $(1.98 \pm 0.15 \mathrm{~h})$ in comparison with time recovery recorded in the animals of $\mathrm{C}$ group $(4.52 \pm 0.10 \mathrm{~h})$. Neostigmine is an irreversible inhibitor of acetylcholinesterase (AChE) (21) since neostigmine stops cholinesterase from breaking down acetylcholine at the junctions between the nerves and the muscle cells. This prolongs the action of acetylcholine at the nerve endings and gives it more chance to act on the remaining acetylcholine receptors. Acetylcholine is known to cause a slow depolarization by blocking a tonically-active $\mathrm{K}^{+}$current, which increases neuronal excitability and may opposite the hyperpolarization status due to toxic dose of ivermectin which is exerting its effect through GABA receptor agonist. However, due to the presence of quaternary nitrogen in its structure, neostigmine is not simply crossing the blood-brain barrier and the crossing can occur only in exceptional conditions (20). 
Table 2. Signs of poisoning and mortality outcome that developed according to different doses of ivermectin in male Balb-C mice according to Up and Down method

\begin{tabular}{|c|c|c|c|}
\hline Dose mg/kg BW & Clinical signs during $24 \mathrm{hs}$ & Time of sings appeared & Results $(\mathbf{O}, \mathbf{X})$ \\
\hline \multirow[t]{7}{*}{100} & grooming, piloerection & $10 \mathrm{~min}$ & $\mathbf{X}$ \\
\hline & anorexia, muscular tremors & $60 \mathrm{~min}$ & \\
\hline & convulsions & $90 \mathrm{~min}$ & \\
\hline & depression, arched back & $2 \mathrm{~h}$ & \\
\hline & crippled & $2.30 \mathrm{~h}$ & \\
\hline & recumbency & $3 \mathbf{h}$ & \\
\hline & respiratory arrest, death & $3 \mathrm{~h}$ & \\
\hline \multirow[t]{7}{*}{80} & grooming, piloerection & $20 \mathrm{~min}$ & $\mathbf{X}$ \\
\hline & anorexia, muscular tremors & $60 \mathrm{~min}$ & \\
\hline & convulsions & $90 \mathrm{~min}$ & \\
\hline & depression & $2.45 \mathrm{~h}$ & \\
\hline & crippled & $4 \mathrm{~h}$ & \\
\hline & recumbency & $5 \mathrm{~h}$ & \\
\hline & respiratory arrest, death & $6 \mathrm{~h}$ & \\
\hline \multirow[t]{4}{*}{60} & grooming & $1 \mathrm{~h}$ & $\mathbf{O}$ \\
\hline & lethargy & $5 \mathrm{~h}$ & \\
\hline & depression & $7 \mathrm{~h}$ & \\
\hline & recovery & $20 \mathrm{~h}$ & \\
\hline \multirow[t]{5}{*}{80} & grooming, piloerection & $10 \mathrm{~min}$ & $\mathbf{X}$ \\
\hline & tremor & $15 \mathrm{~min}$ & \\
\hline & depression & $4 \mathrm{~h}$ & \\
\hline & crippled & $8 \mathrm{~h}$ & \\
\hline & recumbency, death & $9 \mathrm{~h}$ & \\
\hline \multirow[t]{5}{*}{60} & grooming, piloerection & $45 \mathrm{~min}$ & $\mathbf{x}$ \\
\hline & tremor & $2 \mathrm{~h}$ & \\
\hline & convulsions & $6 \mathrm{~h}$ & \\
\hline & depressions & $8 \mathrm{~h}$ & \\
\hline & recumbency, death & $9 \mathrm{~h}$ & \\
\hline \multirow[t]{4}{*}{40} & grooming & $2 \mathrm{~h}$ & $\mathbf{O}$ \\
\hline & mild tremor & $5 \mathrm{~h}$ & \\
\hline & depressions & $6 \mathrm{~h}$ & \\
\hline & recovery & $9 \mathrm{~h}$ & \\
\hline
\end{tabular}


The animals in CT group (treated simultaneously with both $30 \mu \mathrm{g} / \mathrm{kg} \mathrm{BW}$ neostigmine and $3.5 \mu \mathrm{g} / \mathrm{kg}$ BW flumazenil) showed a significant increase $(P<0.05)$ in time recovery $(40.25 \pm 2.78 \mathrm{~h})$ in comparison with the time recovery recorded in animals of both FT and NT groups, as well as the C group (Figure 1). The poisoned mice showed cholinergic toxicity signs such as convulsion, tremors, constriction of pupils, and paralysis. In addition, two mice were dead within $10 \mathrm{~h}$ after receiving the combination of these two agents. We hypothesized that the synergistic effect of flumazenil and neostigmine exacerbated the acute toxicity of ivermectin, which is due to the exaggerated effect of accumulated acetylcholine postsynaptic due to neostigmine action, while flumazenil antagonizes the GABA receptors. We could conclude that both flumazenil and neostigmine medicines have the potential to overcome ivermectin acute poisoning in Balb-C mice, but flumazenil is more efficient one, while the combination of them have a bad prognosis.

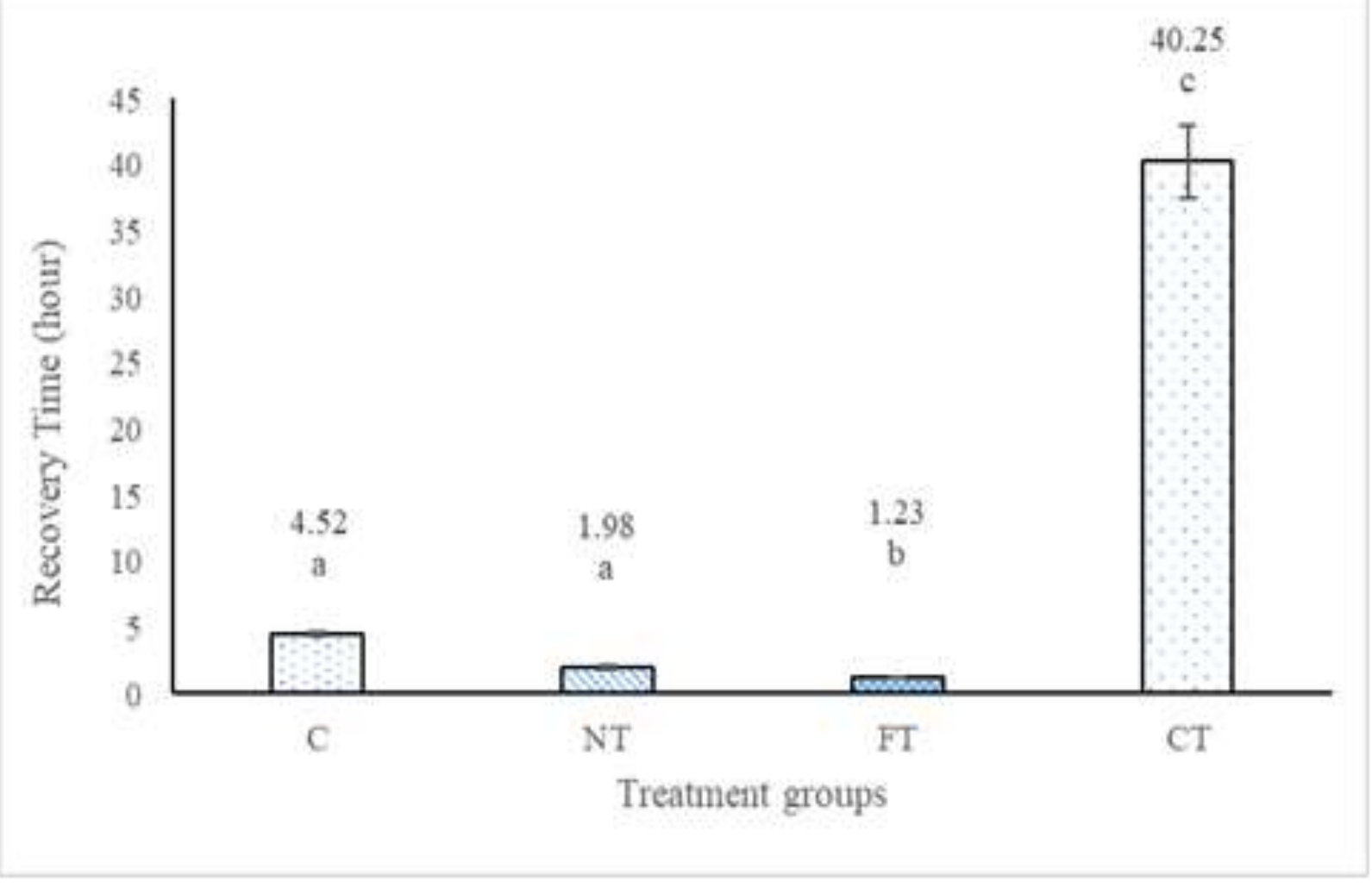

Figure 1. Recovery time/h of ivermectin acute poisoned male Bulb-C mice treated with different therapeutic agents, Mean \pm SEM (each group $n=6) . C=C$ Control group, poisoned with $10 \mathrm{mg} / \mathrm{kg} \mathrm{BW}$ ivermectin orally and treated with distilled water orally; NT=neostigminetreated group, poisoned with $10 \mathrm{mg} / \mathrm{kg} \mathrm{BW}$ ivermectin orally and treated with $60 \mu \mathrm{g} / \mathrm{kg} \mathrm{BW}$ of neostigmine intraperitoneally; FT=flumazenil-treated group, poisoned with $10 \mathrm{mg} / \mathrm{kg} \mathrm{BW}$ ivermectin orally and treated with $7 \mu \mathrm{g} / \mathrm{kg} \mathrm{BW}$ of flumazenil intraperitoneally; CT=combined-treated group, poisoned with $10 \mathrm{mg} / \mathrm{kg} \mathrm{BW}$ ivermectin orally and treated with $3.5 \mu \mathrm{g} / \mathrm{kg} \mathrm{BW}$ flumazenil $+30 \mu \mathrm{g} / \mathrm{kg}$ BW neostigmine intraperitoneally 


\section{REFERENCES}

1. Alexander, S. P. H., A. Mathie and J. A. Peters. 2001. Ligand-gated ion channels. Br J Pharmacol. 164: S115-35

2. Bissonnette, S., M. Paradis, I. Daneau and D. W. Silversides. 2009. The ABCB1 1and mutation is not responsible for sub chronic neurotoxicity seen in dog of noncolli breeds following macrocyclic treatment for generalized demodicosis. Vet. Dermatol. 20:60-66

3. Campbell, W. C. and G.W. Benz. 1984. Ivermectin: a review of efficacy and safety. J. Vet. Pharmacol.Ther. 7: 1-16

4. Chandler, R. E. 2018. Serious neurological adverse events after ivermectin-do they occur beyond the indication of onchocerciasis? Am J Trop Med Hyg.98:382-8

5. Crump, A. and S. Ōmura. 2011.Ivermectin, 'wonder drug' from Japan: The human use perspective. ProcJpnAcadSer B PhysBiol Sci. 87:13-28

6. Dixon, W. J. 1980. Efficient Analysis of Experimental Observation. Am. Rev. Pharmacol. Toxically. 20:441-462

7. Ghulam, M., A. Jabbar, K. Mohammad and S. Muhammad. 2004.Use of Neostigmine in Massive Ivermectin Toxicity in Cat.Veterinary and human Toxicology. 46:28-29

8. Hayes, W. J and E. R. Laws. 1991. Handbook of Pesticide Toxicology. Vol 2.Classes of pesticides. Academic Press Inc, San Diego, California,pp: 1576

9. Henson, P. M., C. D. Mackenzie. and W. G. Spector. 1979. Inflammatory reactions in onchocerciasis: A report on current knowledge and recommendations for further study. Bull World Health Organ. 57:667-82

10. Howland, R. D., M. J. Mycek, R. A. Champe. P. C. Harvey and M. J. Mycek. 2008. .Pharmacology $3^{\text {rd }}$ ed, Lippincott's Illustrated Reviews, pp:51

11. IBM SPSS Statistics Software 2013. Version 22.0. SPSS Inc., Chicago, Illinois, U.S.A

12. Klaassen, D. 1986. Principle of toxicology. In: Casarett and Doull's Toxicology, the Basic Science of Poisons $3^{\text {rd }}$ Ed. Macmillan Publish Co. Toronto. Load; pp:13
13. Kucken, A. M., J. A. Teissére, J. SeffingaClark, D. A. Wagner and C. Czajkowski. 2003. Structural requirements for imidazobenzodiazepine binding to $\operatorname{GABA}(\mathrm{A})$ receptors. MolPharmacol. 63: 289-96

14. Klement, P. 1996. An oral Ivermectin regimen that eradicates pinworm (Syphaciaspp) in laboratory rats and mice. Lab. Anim. Sci. 46: 286-90

15. Lankas, G. R., M. E. Cartwright and D. Umbenhauer. 1997. P-glycoprotein deficiency in a subpopulation of CF1mice enhances avermectin-induced neurotoxicity.ToxicolApplPharmacol. 143:357-365

16. Lankas G. R. and L. R. Gordon. 1989. Toxicology .In".Ivermectin and abamectin ". WC Campbell,(Ed.) Springer-Verlag. New York, USA

17. MSD (Merck Sharp and Dohme). 1988. Poison Control Monograph.Ivermectin. Division of Merck and Co Ltd, West Point, Pennsylvania,pp: 18

18. Pampiglione, S., G. Majori, G. Petrangeli and R. Romi. 1985. "Avermectins, MK-933 and MK-936, for mosquito control". Trans. R. Soc. Trop. Med. Hyg: 79: 797-9

19. Pankaj, K., K. Sawita, B. Sonam, D. Desh, P. Arun, P. Brijesh, R. Chandrama and S. K. Dixi. 2018. Therapeutic Management of Ivermectin Toxicity in a Calf: A Case Report.Int.J.Curr.Microbiol. App.Sci. 7: 19641969

20. Parisi, P. and A. Francia. 2000. A female with central anticholinergic syndrome responsive to neostigmine. Pediatr. Neurol. 23: 185-187

21. Pohanka, M. 2011. Cholinesterases, a target of pharmacology and toxicology. Biomed Pap Olomouc. 155: 219-223

22. Robertson, B. 1989. Actions of anesthetics and avermectin on GABAA chloride channels in mammalian dorsal root ganglion neurones. Br. J. Pharmacol. 98: 167-176

23. Schonrock, B. and J. Bormann. 1993. Activation of $\mathrm{Cl}$ - channels by avermectin in rat cultured hippocampal neurons. Naunyn Schmiedebergs Arch. Pharmacol. 348: 628632 
24. Serratosa, J., A. Blass, B. Rigau, B. 25. Trailović, S. and T. Nedeljković. 2011. Mongrell, T. Rigau, M. Tortadès, E. Tolosa, Central and Peripheral Neurotoxic Effects of C. Aguilar, O. Ribó and J. Balagué. Ivermectin in Rats. J. Vet. Med. Sci. 73:5912006.Residues from veterinary medicinal products, growth promoters and performance enhancers in food-producing animals: a European Union Perspective. Rev. Sci. Tech. Off. Int. Epiz. 25: 637-653 599

26. Wang, C. C. and S. S. Pong. 1982. Actions of avermectinB1a on GABA Nerves. Prog.Clin. Biol. Res. 97: 373 